\title{
Аквакультура
}

УДК 639.3.05:619:616-093/-098

doi: 10.15389/agrobiology.2021.2.326rus

\section{ГЕМАТОЛОГИЧЕСКИЕ ПОКАЗАТЕЛИ ЕВРОПЕЙСКОГО ОКУНЯ (Perca fluviatilis Linnaeus, 1758) ПРИ ПАРАЗИТАРНОЙ ИНВАЗИИ}

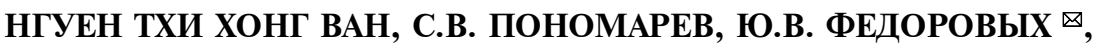 \\ Ю.Н. ГРОЗЕСКУ, А.А. БАХАРЕВА, И.В. ВОЛКОВА, В.И. ЕГОРОВА, \\ Ю.В. СЕРГЕЕВА
}

Европейский окунь (Perca fluviatilis Linnaeus, 1758) обитает во многих водоемах Евразии и имеет промысловое значение, однако в естественной среде рыба часто подвержена инвазионным болезням, что трудно контролировать при промышленных масштабах переработки. Патогенная нематода Eustrongylides excisus широко распространена в дельте реки Волга и в больших количествах встречается у окуня. В настоящей работе впервые проведена сравнительная оценка гематологического статуса зараженных окуней естественных популяций и здоровых особей. Целью работы было изучение влияния поражения речного окуня различными инвазиями на некоторые биологические характеристики и физиологические показатели выращиваемых рыб. Исследования проводили на особях европейского окуня Perca fluviatilis (Linnaeus, 1758) обоих полов в возрасте от 0 (сеголетки) до 4 лет (четырехлетки), выловленных из естественных водоемов Нижней Волги (реки Болышая Болда и Белый Ильмень, Астраханская область) в период с сентября 2016 года по июнь 2019 года. Работу выполняли на базе Инновационного центра «Биоаквапарк научно-технический центр аквакультуры» (ФГБОУ ВО Астраханский государственный технический университет). Определяли абсолютную длину тела, длину тела до конца чешуйного покрова, массу тела и возраст рыб, рассчитывали коэффициент упитанности по Фультону. Паразитологическое исследование проводили по стандартной методике с определением паразитов в коже, плавниках, ротовой полости, жабрах, глазах, сердце, брюшной полости, мышцах, головном и спинном мозге. Кровь для анализа брали из хвостовой вены прижизненно. Более чем у 55 \% выловленных особей речного окуня при вскрытии были обнаружены нематоды. У зараженных особей нематоды находились в печени (30\%), брюшной полости (45\%), кишечнике (10\%), мышцах (15\%), жабрах (5\%). Во внутренних органах и в их оболочках паразиты присутствовали как в свободном, так и в инкапсулированном состоянии, причем наиболее многочисленными были Eustrongylides excisus. При зараженности этими паразитами у рыб снижалась средняя масса тела и коэффициент упитанности по сравнению со здоровыми особями того же возраста. Однако выявленное замедление роста у больных особей было статистически недостоверным (p > 0,05), тогда как коэффициент упитанности оказался достоверно меньше, чем у незараженных рыб (трехлетки, р < 0,01). Результаты проведенных анализов показали, что при эустронгилидозе у $\boldsymbol{P}$. fluviatilis появились симптомы анемии, угнетение эритропоэза (снижалась доля бластных форм клеток эритроцитарного ряда), происходило усиление лейкопоэза (в лейкоцитарной формуле увеличивалось число нейтрофилов, моноцитов, лимфобластов). Наблюдалось значительное снижение числа эритроцитов в крови $\left(83,01 \times 10^{4} \pm 4,17 \times 10^{4}\right.$ у больных рыб против $137,22 \times 10^{4} \pm 5,26 \times 10^{4}$ кл/мм ${ }^{3}$ у здоровых $)$, концентрации общего белка $(40,81 \pm 1,19$ против $48,97 \pm 2,07$ г/л) и холестерина $(5,17 \pm 0,28$ против $6,81 \pm 0,30$ ммоль/л) в сыворотке крови. Также отмечали повышение содержания гемоглобина на эритроцит (mean corpuscular hemoglobin, МСН), скорости оседания эритроцитов, общего числа лейкоцитов, тромбоцитов у зараженных особей по сравнению с незараженными. Доля патологиче-

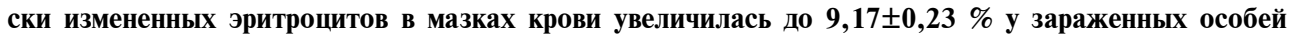

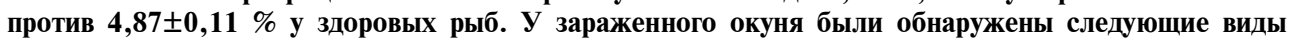
патологически измененных клеток: изменения цитоплазмы клеток, изменение ядра клеток, дегенеративные изменения клетки, изменения, связанные с делением клетки.

Ключевые слова: европейский окунь, паразиты, нематоды, гематологические показатели, анемия, эустронгилидоз, кровь.

По объему выращивания и вылова европейский окунь (Perca fluviatilis Linnaeus, 1758) уступает лососевым (Salmonidae) и карповым (Cyprinidae) рыбам. Увеличение его численности в основном происходит за счет интродукции и естественного размножения. Так, в Швеции европейский (речной) окунь широко распространен во многих водоемах. В Дании методами аквакультуры ежегодно производят около 350 тыс. двухграммовой молоди этого вида, которую экспортируют в Швейцарию и Ирландию. В Ирландии речной окунь стал потенциальным объектом аквакультуры еще в 1995 году (1- 
4). Важно отметить, что объем выращиваемого товарного речного окуня за три последних года увеличился в 2 раза по сравнению с данными предыдущих лет. Основные производители европейского окуня - Франция, Чешская Республика, Нидерланды, Украина, Тунис, Австралия $(1,5)$.

В России до настоящего времени P. fluviatilis считался сорной рыбой, малоценным объектом промысла. Во многом это объясняется тем, что в естественных водоемах окунь в значительной степени заражен различными паразитами, в особенности нематодами Eustongylides, Anisakis (6-10). Такая рыба часто остается бесплодной (11), отстает в росте и развитии, ее масса на 20-25 \% ниже по сравнению с незараженными особями (12).

В целом отмечается, что по ряду причин (из-за изменений в кулинарных привычках, глобализации поставок продуктов, развития туризма, распространения чужеродных видов) нематодозы рыб создают угрозу для здоровья человека, которую не следует недооценивать (13-15).

Получение свободных от паразитов здоровых особей речного окуня возможно при развитии индустриального выращивания особей этого вида. Однако в отсутствие условий для создания собственного ремонтно-маточного стада в таких хозяйствах приходится отлавливать производителей из естественных популяций для последующей нерестовой кампании. Возникает необходимость оценки рыбоводно-биологических показателей и физиологического статуса самок и самцов окуня при их бонитировке.

В настоящем исследовании мы впервые установили ряд гематологических и биохимических показателей, подтверждающих физиологический статус зараженных окуней из естественных популяций. Полученные данные могут быть основой при разработке контрольных показателей физиологоиммунологического состояния европейского окуня как в природе, так и при культивировании этого объекта в искусственных условиях, в том числе в рамках селекционно-племенных программ.

Целью работы было изучение влияния паразитарных инвазий на некоторые биологические и физиологические характеристики европейского окуня Perca fluviatilis L. для выявления показателей, которые могут быть использованы при оценке состояния здоровья рыбы в процессе выращивания и формирования ремонтно-маточных стад в рыбоводных хозяйствах.

Методика. Исследования проводили на особях европейского окуня Perca fluviatilis (Linnaeus, 1758) обоих полов в возрасте от 0 (сеголетки) до 4 лет (четырехлетки), выловленных из естественных водоемов Нижней Волги (реки Большая Болда и Белый Ильмень, Астраханская область) в период с сентября 2016 года по июнь 2019 года. Работу выполняли на базе Инновационного центра «Биоаквапарк - научно-технический центр аквакультуры» (ФГБОУ ВО Астраханский государственный технический университет).

Учитывали абсолютную длину тела, длину тела до конца чешуйного покрова, массу тела и возраст рыб, рассчитывали коэффициент упитанности по Фультону. Возраст рыб определяли по годовым кольцам чешуи (16). Паразитологическое исследование проводили по стандартной методике с определением паразитов в коже, плавниках, ротовой полости, жабрах, глазах, сердце, брюшной полости, мышцах, головном и спинном мозге (17). Для определения видовой принадлежности паразитов использовали ключи и рисунки $(18,19)$. Интенсивность и экстенсивность инвазии рассчитывали согласно описанию (20).

Кровь для анализа брали из хвостовой вены прижизненным 
способом (21). Фиксированные 95 \% этанолом мазки крови окрашивали гематоксилином и эозином по Романовскому («Методические указания по проведению гематологического обследования рыб: Сборник инструкций по борьбе с болезнями рыб». Часть 2. М., 1999) и изучали под микроскопом (БИОМЕД 6 LED, ООО «Биомед», Россия) с иммерсией (×100). Для микрофотосъемки использовали фотонасадку DMC-510 («Panasonic», Япония). При дифференцировке форменных элементов применяли классификацию форменных клеток крови рыб по Н.Т. Ивановой (1983), изучали морфологически измененные эритроциты $(21,22)$. Концентрацию гемоглобина определили гемоглобинцианидным методом с применением фотоэлектроколориметра КФК-3 (АО «ЗОМЗ», Россия). Подсчет эритроцитов в одном миллилитре крови осуществляли в камере Горяева. Содержание гемоглобина в одном эритроците определяли косвенным способом. Скорость оседания эритроцитов (СОЭ) оценивали в аппаратах Панченкова («Методические указания по проведению гематологического обследования рыб: Сборник инструкций по борьбе с болезнями рыб». Часть 2. М., 1999).

Показатели, характерные для белкового и липидного обмена рыб, определяли методами, основанным на принципе измерения оптической плотности проб, полученных от здоровых и инфицированных особей, в сравнении с калибровочным растворами, с применением фотоэлектроколориметра КФК-3 (Россия). Концентрацию общего белка оценивали по биуретовой реакции: по 0,1 мл негемолизированной сыворотки помещали в пробирки с 5 мл трансформирующего раствора (раствора биуретового реагента). Количество холестерина также определяли колориметрически в соответствии с описанием (23).

Результаты обрабатывали статистически в программах Microsoft Excel 2010 и JASP-1 (https://jasp-stats.org). Были вычислены средние значения $(M)$, стандартные отклонения $( \pm \sigma)$, стандартные ошибки средней $( \pm \mathrm{SEM})$. Для подтверждения достоверности различий использовали $t$-критерий Стьюдента (24).

Результаты. Более чем у 55 \% выловленных особей речного окуня при вскрытии были обнаружены нематоды (табл. 1). У 5 \% паразиты были обнаружены только с помощью микроскопа. У зараженных особей нематоды находились в печени (30\%), брюшной полости (45\%), кишечнике (10\%), мышцах (15\%), жабрах (5\%). Во внутренних органах и в их оболочках паразиты присутствовали как в свободном состоянии, так и в инкапсулированном, причем наиболее многочисленными были Eustrongylides excisus (см. табл. 1).

1. Видовой состав нематод и показатели зараженности ими у европейского окуня (Perca fluviatilis Linnaeus, 1758), выловленного из рек Большая Болда и Белый Ильмень (Нижняя Волга, Астраханская обл., 2016-2019 годы)

\begin{tabular}{|c|c|c|c|}
\hline Вид & Локализация & $\begin{array}{l}\text { Экстенсивность } \\
\text { инвазии, \% }\end{array}$ & $\begin{array}{l}\text { Интенсивность } \\
\text { инвазии, эк3. }\end{array}$ \\
\hline Anisakis schupakovi & $\begin{array}{l}\text { Брюшная полость, кишечник, } \\
\text { висцеральный жир }\end{array}$ & 51 & $1-19$ \\
\hline Eustrongylides excisus & $\begin{array}{l}\text { Брюшная полость, желудок, печень, } \\
\text { мышцы, висцеральный жир }\end{array}$ & 60 & $5-34$ \\
\hline Camallanus lacustris & Висцеральный жир, кишечник & 30 & $1-7$ \\
\hline
\end{tabular}

Нематод Eustrongylides spp. обнаруживают в мышцах, полостях тела и во внутренних органах рыб $(25,26)$, в том числе у P. fluviatilis $(9,27)$. Гистопатологические изменения, наблюдаемые у $P$. fluviatilis при инвазии этого паразита, включали дегенерацию и некроз мышц, распространяю- 
щиеся на саркоплазму, базальную пластинку сарколеммы, эндомизиальные клетки соединительной ткани и капилляры (27). При этом иммуногистохимическое окрашивание выявило многочисленные пролиферирующие клетки в толще капсулы и в непосредственной близости от личинки Eustrongylides sp., что, как предполагают авторы, свидетельствовало об инициации восстановления поврежденной нематодой мышцы (27). Сходные гистопатологические проявления, мышечную атрофию и хроническую воспалительную реакцию отмечали S. Guagliardo с соавт. (25) у Galaxias maculatus.

Наши наблюдения показали, что при зараженности Anisakis schupakovi, Eustrongylides excisus и Camallanus lacustris у особей P. fluviatilis снижается средняя масса тела и коэффициент упитанности по сравнению со здоровыми особями того же возраста. Однако выявленное замедление роста у больных особей было статистически недостоверным (p > 0,05), тогда как коэффициент упитанности у зараженных рыб оказался достоверно меньше, чем у незараженных $(\mathrm{p}<0,01)$ (табл. 2$)$.

2. Биологические показатели у европейского окуня (Perca fluviatilis Linnaeus, 1758) разного возраста, зараженного и не зараженного паразитическими нематодами ( $M \pm \mathrm{SEM}$, реки Большая Болда и Белый Ильмень, Нижняя Волга, Астраханская обл., 2016-2019 годы)

\begin{tabular}{|c|c|c|c|c|}
\hline \multirow[b]{2}{*}{ Показатель } & \multicolumn{2}{|c|}{ Двухлетки } & \multicolumn{2}{|c|}{ Трехлетки } \\
\hline & $\begin{array}{c}\text { зараженные } \\
(n=17)\end{array}$ & $\begin{array}{c}\text { незараженные } \\
(n=7)\end{array}$ & $\begin{array}{c}\text { зараженные } \\
(n=17)\end{array}$ & $\begin{array}{c}\text { незараженные } \\
(n=7)\end{array}$ \\
\hline Macca, г & $47,21 \pm 4,19$ & $54,33 \pm 5,14$ & $91,77 \pm 7,85$ & $106,20 \pm 10,06$ \\
\hline $\begin{array}{l}\text { Длина абсолютная, см } \\
\text { Длина до конца }\end{array}$ & $15,36 \pm 0,32$ & $16,89 \pm 0,41$ & $19,68 \pm 0,60$ & $20,11 \pm 0,72$ \\
\hline чешуйного покрова, см & $13,34 \pm 0,41$ & $13,92 \pm 0,37$ & $16,92 \pm 0,47$ & $17,30 \pm 0,56$ \\
\hline $\begin{array}{l}\text { Коэффициент } \\
\text { упитанности по Фультону }\end{array}$ & $1,99 \pm 0,08$ & $2,01 \pm 0,07$ & $1,89 \pm 0,09 *$ & $2,05 \pm 0,10$ \\
\hline
\end{tabular}

У зараженных рыб выявляли снижение концентрации гемоглобина

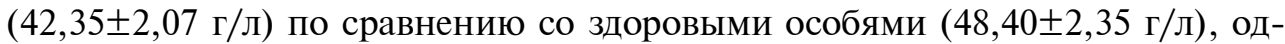
нако эти различия были недостоверны (p >0,05) (табл. 3).

3. Гематологические и биохимические показатели у европейского окуня (Perca fluviatilis Linnaeus, 1758), зараженного и не зараженного паразитическими нематодами ( $M \pm \mathrm{SEM}$, реки Большая Болда и Белый Ильмень, Нижняя Волга, Астраханская обл., 2016-2019 годы)

\begin{tabular}{l|c|c}
\hline \multicolumn{1}{c|}{ Показатель } & $\begin{array}{c}\text { Зараженные особи } \\
(n=17)\end{array}$ & $\begin{array}{r}\text { Незараженные особи } \\
(n=7)\end{array}$ \\
\hline Гемоглобин, г/л & $42,35 \pm 2,07$ & $48,40 \pm 2,35$ \\
Скорость оседания эритроцитов (СОЭ), мм/ч & $4,50 \pm 0,12^{* *}$ & $3,34 \pm 0,22$ \\
Общее число эритроцитов, ×104/мм 3 & $83,01 \pm 4,17^{* *}$ & $137,22 \pm 5,26$ \\
Содержание гемоглобина в эритроците & & \\
(теап согрuscular hemoglobin, МСН), пг & $51,03 \pm 2,12^{*}$ & $28,34 \pm 1,91$ \\
Общий белок, г/л & $40,81 \pm 1,19^{* *}$ & $48,97 \pm 2,07$ \\
Холестерин, ммоль/л & $5,17 \pm 0,28^{* *}$ & $6,81 \pm 0,30$ \\
* ** Различия между зараженными и незараженными особями статистически значимы соответственно при \\
р $<0,05$ и р $<0,01$.
\end{tabular}

Полученные данные согласуются с имеющимися в литературе сведениям. Так, у сазана Cyprinus carpio при паразитарной инвазии также наблюдалось значительное снижение концентрации гемоглобина в крови (28). В то же время в исследованиях гематологических показателей судака Sander lucioperca, обитающего в водно-болотных угодьях Анзали (Иран), была установлена повышенная концентрация гемоглобина по сравнению с незараженными особями, однако различия также оказались недостоверными (29). По мнению многих авторов, европейский окунь обладает 
значительной резистентностью к абиотическим и биотическим факторам среды, в том числе к паразитарной инвазии (30-34), поэтому при заражении содержание гемоглобина в крови изменяется неоднозначно.

Число эритроцитов в крови у зараженных окуней значительно уменьшалось и составило $83,01 \times 10^{4} \pm 4,17 \times 10^{4}$ кл/мм ${ }^{3}$, в то время как у

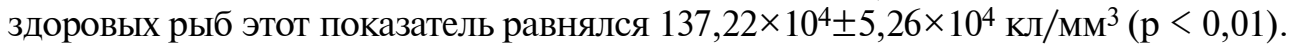
В работах других авторов уменьшение количества эритроцитов отмечалось не только у сазана, но и африканского сома Clarias gariepinus, при заражении паразитами, что свидетельствовало об анемии (35). В связи со снижением количества эритроцитов увеличилась концентрация гемоглобина в одном эритроците (МСН). Различия по этому показателю между зараженными и здоровыми особями речного окуня были достоверны $(51,03 \pm 2,12$ против 28,34 $\pm 1,91$ пг, р < 0,01). Увеличилось и значение СОЭ $(4,50 \pm 0,12$

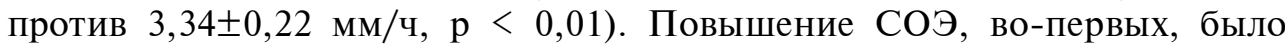
следствием снижения количества эритроцитов, во-вторых, указывало на наличие воспалительного процесса в организме рыб под влиянием паразитов $(36,37)$. Изучение инвазии Eustrongylides sp. у змееголова Channa punctatus показало, что среднее число эритроцитов, гематокрит и содержание гемоглобина были значительно выше $(\mathrm{p}<0,01)$ у незараженных рыб, в то время как величина МСН достоверно повышалась (p < 0,01) у инфицированных рыб (26).

Согласно нашим наблюдениям, концентрация общего белка в сыворотке крови у здоровых окуней $P$. fluviatilis составляла 48,97 2 2,07 г/л,

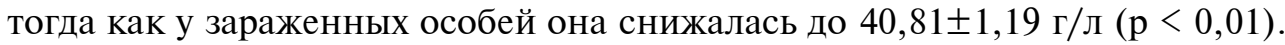
У C. punctatus тоже отмечали значительные различия по концентрации общего белка, а также глюкозы между неинфицированными и инфицированными Eustrongylides sp. особями (26). Эти же авторы показали существенное $(\mathrm{p}<0,01)$ повышение активности аспартатаминотрансферазы, аланинаминотрансферазы, щелочной фосфатазы и содержания холестерина у инфицированных Eustrongylides sp. особей по сравнению с неинфицированными (26).

Результаты микроскопического исследования мазков крови рыб показали, что у зараженных окуней уменьшилась доля бластных и молодых клеток эритроцитарного ряда $(0,47 \pm 0,04 \%)$ по сравнению со здоровыми особями $(6,36 \pm 0,23 \%)$. Это указывает на угнетение эритропоэза при стрессовом воздействии паразита на организм рыб. Доля патологически изме-

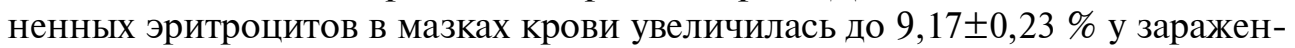

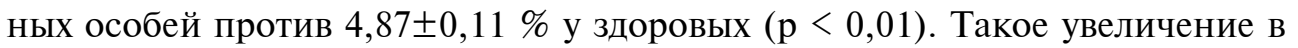
основном происходило за счет пойкилоцитов и шизоцитов, которые появились вследствие снижения прочности клеточной мембраны, что было симптомом анемии. Так, в работе G. Chiocchia с соавт. (38) под влиянием паразитов происходило набухание эритроцитов из-за изменения осмотического градиента.

В работах многих авторов показано, что при паразитарной инвазии наиболее существенно изменяется лейкоцитарная формула и количество лейкоцитов в крови $(26,33,39,40)$. В нашем исследовании было выявлено

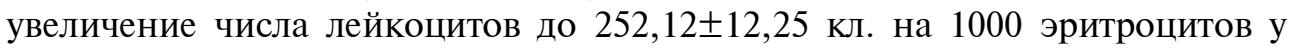

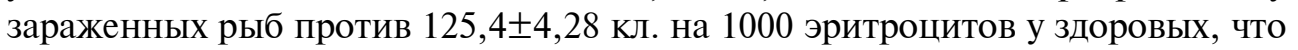
связано с ролью лейкоцитов в организме, поскольку они отвечают за защитную реакцию иммунной системы при паразитарной инвазии $(28,41)$. Кроме того, снижалось количество тромбоцитов на 1000 эритроцитов. В лейкоцитарной формуле наблюдались сдвиги состава клеток в сторону 
нейтрофилов и моноцитов (табл. 4).

4. Результаты микроскопического изучения мазков крови у европейского окуня (Perca fluviatilis Linnaeus, 1758), зараженного и не зараженного паразитическими нематодами ( $M \pm \mathrm{SEM}$, Нижняя Волга, Астраханская обл., 20162019 годы)

\begin{tabular}{|c|c|}
\hline Показатель & Зараженные особи $(n=17) \mid$ Незараженные особи $(n=7)$ \\
\hline \multicolumn{2}{|c|}{$\begin{array}{lll}\text { Клетки эритропоэзтического } & \text { ряда, \% } \\
\end{array}$} \\
\hline Эритробласты & $0,45 \pm 0,33$ \\
\hline Оксифильные нормобласты & $0,13 \pm 1,32 *$ \\
\hline Полихроматофильные нормобласты & $0,02 \pm 0,71$ \\
\hline Патологи че с ки из & м ененные формы эритроцитов, $\%$ \\
\hline Пойкилоцитоз & $3,98 \pm 0,14$ \\
\hline Заостренные & $0,59 \pm 0,02$ \\
\hline Грушевидные & $0,28 \pm 0,04$ \\
\hline Многогранные & $3,11 \pm 0,78$ \\
\hline Смешение ядра к периферии & $1,18 \pm 0,02^{* *}$ \\
\hline Шизоцитоз & $1,82 \pm 0,07^{* *}$ \\
\hline Олигохромазия & $1,22 \pm 0,12$ \\
\hline Деформация ядра & $0,17 \pm 0,05$ \\
\hline Общая доля патологических клеток & $9,17 \pm 0,23^{* *}$ \\
\hline \multicolumn{2}{|c|}{ Л ейкоцитарн ая формула, \% } \\
\hline Лимфоциты & $75,77 \pm 0,98^{* *}$ \\
\hline Нейтрофилы & $3,57 \pm 0,32^{* *}$ \\
\hline Моноциты & $7,55 \pm 0,46^{* *}$ \\
\hline Лимфобласты & $7,27 \pm 0,67$ \\
\hline Миелоциты & $3,27 \pm 0,74^{* *}$ \\
\hline Промиелоциты & $2,57 \pm 0,28 * *$ \\
\hline Число лейкоцитов на 1000 эритроцитов & $252,12 \pm 12,25^{* *}$ \\
\hline Числотромбоцитов на 1000 эритроцитов & $2,10 \pm 2,01$ \\
\hline \multicolumn{2}{|c|}{$\begin{array}{l}\text { П р и м е ч а н и е. Прочерки означают, что соответствующие формы не наблюдали. } \\
\text { *, ** Различия между зараженными и незараженными особями статистически значимы соответственно при } \\
\text { р }<0,05 \text { и р }<0,001 .\end{array}$} \\
\hline
\end{tabular}

Таким образом, у окуней, выловленных из естественных водоемов нижней Волги, более чем в половине случаев была зафиксирована паразитарная инвазия. Наиболее многочисленными из обнаруженных нематод оказались Eustrongylides excisus. У рыб, зараженных паразитическими нематодами, наблюдалось значительное снижение количества эритроцитов в крови, концентрации общего белка и содержания холестерина в сыворотке крови. У зараженных особей также было выявлено увеличение концентрация гемоглобина в эритроците, СОЭ, общего количества лейкоцитов, тромбоцитов по сравнению с аналогичными показателями у незараженных особей. Анализ состава форменных элементов крови у зараженных окуней показал угнетение эритропоэза, что служит признаком анемии. Увеличение доли нейтрофилов и моноцитов, доли лимфобластов в лейкоцитарной формуле указывало на усиление лейкопоэза, в том числе нейтрофилеза в организме рыб при паразитарной инвазии. Полученные в результате информативные показатели имеют перспективу применения для контроля физиолого-иммунологического состояния речного окуня при культивировании в искусственных условиях и проведения селекционно-племенной работы.

\footnotetext{
ФГБОУ ВО Астраханский государственный

технический университет,

414056 Россия, г. Астрахань, ул. Татищева, 16,

e-mail: Hongvannguyen@mail.ru, ya.panama2011@yandex.ru,

jaqua@yandex.ru $₫$, grozesku@yandex.ru, bahareva.anya@yandex.ru,

gridasova@mail.ru, lekaego@mail.ru, js4444@mail.ru
}

Поступила в редакцию

Sel'skokhozyaistvennaya biologiya [Agricultural Biology], 2021, V. 56, № 2, pp. 326-334

HEMATOLOGICAL PARAMETERS OF EUROPEAN PERCH (Perca fluviatilis Linnaeus, 1758) ASSOCIATED WITH PARASITIC 


\title{
INVASIONS
}

\author{
Nguen Thi Hong Van, S.V. Ponomarev, Yu.V. Fedorovykh $\bowtie$, Yu.N. Grozesku, \\ A.A. Bakhareva, I.V. Volkova, V.I. Egorova, Yu.V. Sergeeva
}

Astrakhan State Technical University, 16, Tatishcheva st., Astrakhan, Russia 414056, e-mail: Hongvannguyen@mail.ru, ya.panama2011@yandex.ru, jaqua@yandex.ru (corresponding author $₫$ ), grozesku@yandex.ru, bahareva.anya@yandex.ru, gridasova@mail.ru, lekaego@mail.ru, js4444@mail.ru

ORCID:

Nguen Thi Hong Van orcid.org/0000-0002-6910-2705

Fedorovykh Yu.V. orcid.org/0000-0003-0789-1566

Bakhareva A.A. orcid.org/0000-0002-7724-2425

Egorova V.I. orcid.org/0000-0002-7688-723X

The authors declare no conflict of interests

Ponomarev S.V. orcid.org/0000-0002-2899-8672

Grozesku Yu.N. orcid.org/0000-0002-6691-8696

Volkova I.V. orcid.org/0000-0001-8945-6669

Received November 14, 2019

Sergeeva Yu.V. orcid.org/0000-0001-8811-1378

doi: $10.15389 /$ agrobiology.2021.2.326eng

\section{Abstract}

European perch (Perca fluviatilis Linnaeus, 1758) is widespread in water basins and has a commercial value. However, in the natural environment, fish are often infected with invasive diseases, which exclude its processing for food purposes. Being in the body of fish, parasites produce toxic substances that affect various organs of fish. Widespread in the Volga Delta pathogenic species, Eustrongylides excisus, in large quantities occurs in perch in larval state in the abdominal cavity of the body, in the walls of the intestine, in the liver, in the calf and in the spinal muscle tissue, reaching up to 30 or more parasites per fish. Sexual maturity of the parasite occurs in the stomach of the birds. This disease is peculiar to perch species; larvae of this nematode cause granulomatous inflammatory reaction. In addition, these worms, penetrating deep into the muscles of the perch, spoil the commercial quality of fish, which leads to the culling of fish raw materials and rejection of foodstuff. This work, for the first time, compares the hematological status of infected and healthy perch of natural populations. The work aimed to assess biological and physiological effects of various parasitic invasions on European perch Perca fluviatilis (Linnaeus, 1758). Fish of both sexes at the age from 0 to 4 years were caught in natural reservoirs of the Lower Volga (Bolshaya Bolda and Bely Ilmen rivers, Astrakhan region) in September 2016 to June 2019. The total body length, the length to the end of the scale cover, body weight and age were determined, and the Fulton's fatness coefficient was calculated. The skin, fins, mouth, gills, eyes, heart, abdominal cavity, muscles, brain, and spinal cord of fish were examined for parasitological contamination. Blood for analysis was taken from the tail vein in vivo. Nematodes were found in more than $55 \%$ of the caught perch. Nematodes were found in the liver (30\%), abdominal cavity $(45 \%)$, intestines $(10 \%)$, muscles $(15 \%)$, and gills $(5 \%)$. Parasites were found free within the body cavity, or encapsulated, with Eustrongylides excisus being the most abundant. In the infected fish, the average body weight and body condition coefficient decreased as compared to the healthy fish of the same age. However, the revealed growth retardation in the infected perch was statistically insignificant $(\mathrm{p}>0.05)$, while the body condition coefficient was significantly lower than in uninfected fish ( $\mathrm{p}<0.01$ for 3 -year-old perch). The parasitic infestation of P. fluviatilis with $\mathrm{Eu}$ strongylides nematode caused symptoms of anemia, suppression of erythropoiesis (i.e., a decrease in the proportion of blast forms of the erythrocytic cell series), an increase in the proportion of neutrophils, monocytes, and lymphoblasts in the leucocyte count. In infected perch, the number of red blood cells significantly decreased $\left(83.01 \times 10^{4} \pm 4.17 \times 10^{4}\right.$ vs. $\left.137.22 \times 10^{4} \pm 5,26 \times 10^{4} / \mathrm{mm}^{3}\right)$, as well as the concentration of total protein $(40.81 \pm 1.19$ vs. $48.97 \pm 2.07 \mathrm{~g} / \mathrm{l})$ and blood cholesterol $(5.17 \pm 0.28$ vs. $6.81 \pm 0.30 \mathrm{mmol} / \mathrm{l}$ ). $\mathrm{MCH}$ (mean corpuscular hemoglobin), erythrocyte sedimentation rate, the total number of leukocytes and platelets also increased compared to uninfected fish. The level of pathological red blood cells increased in the infected perch $(9,17 \pm 0,23 \%$ vs. $4,87 \pm 0,11 \%)$. Changes in cell cytoplasm and nucleus, degenerative changes in the cell, changes associated with cell division were the main types of the discovered cell pathology of the infected perch.

Keywords: Perca fluviatilis, European perch, parasites, nematodes, hematological parameters, anemia, eustrongylidosis, blood.

\section{R EF E R EN C ES}

1. Fontaine P. Eurasian perch culture, a way of diversification for freshwater aquaculture. INRA Productions Animales, 2004, 17(3): 189-193.

2. Raitaniemi J., Rask M., Vuorinen P.J. The growth of perch, Perca fluviatilis L., in small Finnish lakes at different stages of acidification. Annales Zoologici Fennici, 1988, 25(3): 209-219.

3. O’Neill E.A., Stejskal V., Clifford E., Rowan N.J. Novel use of peatlands as future locations for the sustainable intensification of freshwater aquaculture production - A case study from the Republic of Ireland. Science of the Total Environment, 2020, 706: 136044 (doi: 10.1016/j.scitotenv.2019.136044). 
4. Setälä J., Laitinen J., Virtanen J., Saarni K., Nielsen M., Honkanen A. Spatial integration of freshwater fish markets in the Nothern Baltic Sea area. Fisheries Research, 2008, 92(2-3): 196206 (doi: 10.1016/j.fishres.2008.01.020).

5. Watson L. The European market of perch (Perca fluviatilis). In: Percid fish culture, from research to production: abstracts and short communications: Namur (Belgium), 23-24 January 2008. P. Fontane, P. Kestemont, F. Teletcha, N. Wang (eds.). Presses Universitaires de Namur, Belgium, 2008: 10-14.

6. Matvienko N., Vaschenko A., Nazarov A., Aishpur A. Eustrongylidosis in predatory fish species of Dnieper reservoirs. Zoology and Ecology, 2015, 25(3): 235-238 (doi: 10.1080/21658005.2015.1057393).

7. Terpugova N.Yu., Kon'kova A.V., Volodina V.V., Voronina E.A. Materialy Vserossiiskoi nauchnoi konferentsii s mezhdunarodnym uchastiem «Sovremennye problemy parazitologii i ekologii. Chteniya posvyashchennye pamyati S.S. Shul'mana». Tol'yatti, 2018: 285-292 [Proc. Russian Conf. «Current problems of parasitology and ecology. Readings dedicated to the memory of S.S. Shulman»] (in Russ.).

8. Volodina V.V., Kon'kova A.V., Voronina E.A. Rybnoe khozyaistvo, 2015, 4: 91-93 (in Russ.).

9. Menconi V., Riina M.V., Pastorino P., Mugetti D., Canola S., Pizzul E., Bona M.C., Dondo A., Acutis P.L., Prearo M. First occurrence of Eustrongylides spp. (Nematoda: Dioctophymatidae) in a subalpine lake in Northwest Italy: new data on distribution and host range. International Journal of Environmental Research and Public Health, 2020, 17(11): 4171 (doi: 10.3390/ijerph17114171).

10. Branciari R., Ranucci D., Miraglia D., Valiani A., Veronesi F., Urbani E., Lo Vaglio G., Pascucci L., Franceschini R. Occurrence of parasites of the genus Eustrongylides spp. (Nematoda: Dioctophymatidae) in fish caught in Trasimeno Lake, Italy. Italian Journal of food Safety, 2016, 5(4): 6130 (doi: 10.4081/ijfs.2016.6130).

11. Kaur P., Shrivastav R., Qureshi T.A. Pathological effects of Eustrongylides sp. larvae (Dioctophymatidae) infection in freshwater fish, Glossogobius giuris (Ham.) with special reference to ovaries. Journal of Parasitic Diseases: official organ of the Indian Society for Parasitology, 2013, 37(2): 245-250 (doi: 10.1007/s12639-012-0173-5).

12. Vasil'kov G.V. Gel'mintozy ryb. Moscow, 1983 [Helminthiasis of fish] (in Russ.).

13. Aibinu I.E., Smooker P.M., Lopata A.L. Anisakis nematodes in fish and shellfish - from infection to allergies. International Journal for Parasitology. Parasites and Wildlife, 2019, 9, 384-393 (doi: 10.1016/j.ijppaw.2019.04.007).

14. Eiras J.C., Pavanelli G.C., Takemoto R.M., Nawa Y. An overview of fish-borne nematodiases among returned travelers for recent 25 years - unexpected diseases sometimes far away from the origin. The Korean Journal of Parasitology, 2018, 56(3): 215-227 (doi: 10.3347/kjp.2018.56.3.215).

15. Zhu G.-L., Tang Y.-Y., Limpanont Y., Wu Z.-D., Li J., Lv Z.-Y. Zoonotic parasites carried by invasive alien species in China. Infectious Diseases of Poverty, 2019, 8: 2 (doi: 10.1186/s40249018-0512-6).

16. Kalaida M.L., Govorkova L.K. Metody rybokhozyaistvennykh issledovanii. St. Petersburg, 2013 [Fisheries research methods] (in Russ.).

17. Mlovastyi K.S. Diagnostika boleznei $i$ vetsanekspertiza ryby: uchebnoe posobie. St. Petersburg, 2013 [Diagnostics of diseases and veterinary examination of fish: a tutorial] (in Russ.).

18. Gaevskaya A.V. Parazity i bolezni ryb Chernogo i Azovskogo morei: I - morskie, solonovatovodnye i prokhodnye ryby. Sevastopol', 2012 [Parasites and diseases of fish of the Black and Azov seas: I - marine, brackish-water and anadromous fish] (in Russ.).

19. Gaevskaya A.V. Parazity i bolezni ryb Chernogo i Azovskogo morei: II - poluprokhodnye i presnovodnye ryby. Sevastopol', 2013 [Parasites and diseases of fish of the Black and Azov seas: II semi-anadromous and freshwater fish] (in Russ.).

20. Fedorov N.M., Firsov N.F., Solov'ev N.A. Veterinarnaya patologiya, 2014, 3-4(49-50): 68-73 (in Russ.).

21. Ivanova N.T. Nekotorye aspekty $k$ osnovam ikhtiogematologii. Rostov-na-Donu, 2002 [Some aspects to ichthyogematology basics] (in Russ.).

22. Zhiteneva L.D, Poltavtseva T.G., Rudnitskaya O.A. Atlas normal'nykh i patologicheski izmenennykh kletok krovi ryb. Rostov-na-Donu, 1989 [Atlas of normal and pathologically altered blood cells of fish] (in Russ.).

23. Meditsinskaya biokhimiya: Laboratornyi praktikum. Pod redaktsiei N.A. Semikolenovoi. Omsk, 2005 [Medical biochemistry: laboratory workshop. N.A. Semikolenova (ed.)] (in Russ.).

24. Lebed'ko E.Ya., Khokhlov A.M., Baranovskii D.I., Getmanets O.M. Biometriya v MS Excel. St. Petersburg, 2018 [Biometrics in MS Excel] (in Russ.).

25. Guagliardo S., Viozzi G., Brugni N. Pathology associated with larval Eustrongylides sp. (Nematoda: Dioctophymatoidea) infection in Galaxias maculatus (Actinopterygii: Galaxiidae) from Patagonia, Argentina. International Journal for Parasitology. Parasites and Wildlife, 2019, 10: 113-116 (doi: 10.1016/j.ijppaw.2019.08.004).

26. Kundu I., Bandyopadhyay P.K., Mandal D.R., Gürelli G. Study of pathophysiological effects of the nematode parasite Eustrongylides sp. on freshwater fish Channa punctatus by hematology, serum biochemical, and histological studies. Turkiye Parazitol. Derg., 2016, 40(1): $42-47$ (doi: 
10.5152/tpd.2016.4551).

27. Dezfuli B.S., Manera M., Lorenzo M., Pironi F., Shinn A.P., Giari L. Histopathology and the inflammatory response of European perch, Perca fluviatilis muscle infected with Eustrongylides sp. (Nematoda). Parasites Vectors, 2015, 8: 227 (doi: 10.1186/s13071-015-0838-x).

28. Panjvini F., Abarghuei S., Khara H., Parashkoh H.M. Parasitic infection alters haematology and immunity parameters of common carp, Cyprinus carpio, Linnaeus, 1758. Journal of Parasitic Diseases, 2016, 40(4): 1540-1543 (doi: 10.1007/s12639-015-0723-8).

29. Rahbar M., Khara H., Hayatbakhsh M., Ahmadnezhad M. Surveying some hematological parameters of perch (Perca fluviatilis, L. 1785) in the Anzali Wetland in Iran. In: International conference on chemical, environmental and biological sciences (ICCEBS'2011). Anzali, 2011: 324-327.

30. Morozinska-Gogol J. Parasite communities of European perch, Perca fluviatilis L. (Actinopterygii: Perciformes: Percidae) from lake Łebsko (Central Coast, Poland). Annals of Parasitology, 2013, 59(2): 89-98.

31. Kamshilov I.M., Zaprudnova R.A. Vestnik Mordovskogo universiteta, 2015, 25(2): 152-157 (doi: 10.15507/VMU.025.201502.152) (in Russ.).

32. Kurtanidze Yu.S., Turitsin V.S. Materialy nauchno-prakticheskoi konferentsii «Nauchnyi vklad molodykh issledovatelei $v$ sokhranenie traditsii i razvitie APK». St. Petersburg, 2016, 1: 147-149 [Proc. Int. Conf. «Scientific contribution of young researchers to the preservation of traditions and the development of the agro-industrial complex»] (in Russ.).

33. Dugarov Zh.N., Pronin N.M. Ekologiya, 2017, 1: 20-27 (doi: 10.7868/S0367059716060044).

34. Zaprudnova R.A., Kamshilov I.M. Vestnik APK Verkhnevolzh'ya, 2013, 4(24): 56-61 (in Russ.).

35. Akoll P., Konecny R., Mwanja W.W., Nattabi J.K., Agoe C., Schiemer F. Parasite fauna of farmed Nile tilapia (Oreochromis niloticus) and African catfish (Clarias gariepinus) in Uganda. Parasitology Results, 2012, 110: 315-323 (doi: 10.1007/s00436-011-2491-4).

36. Petrishko V.Yu., Firsov N.F. Materialy Mezhdunarodnoi nauchno-prakticheskoi konferentsii studentov, magistrantov, aspirantov $i$ molodykh uchenykh «Perspektivy razvitiya nauchnoi i innovatsionnoi deyatel'nosti molodezhi». Pos. Persianovskii, 2016: 159-163 [Proc. Int. Conf. «Prospects for the development of scientific and innovative activities of youth»] (in Russ.).

37. Kamshilov I.M., Zaprudnova R.A., Chalov Yu.P. Biologiya vnutrennikh vod, 2014, 4: 83-85 (doi: 10.7868/S032096521404024X) (in Russ.).

38. Chiocchia G., Motias R. Effect of catecholamines on deformability of red cells from trout: relative roles of cyclic AMP and cell volume. The Journal of Physiology, 1989, 412(1): 321-332 (doi: 10.1113/jphysiol.1989.sp017618).

39. Voronin V.N., Golineva E.A., Dudin A.S. Parazitologiya, 2017, 51(2): 165-169 (in Russ.).

40. Dugarov Zh.N., Pronin N.M. Rossiiskii zhurnal biologicheskikh invazii, 2012, 5(4): $27-35$ (in Russ.).

41. Pronina G.I., Koryagina N.Yu. Metodologiya fiziologo-immunologicheskoi otsenki gidrobiontov. St. Petersburg, 2017 [Methodology of physiological and immunological assessment of aquatic organisms] (in Russ.). 